\title{
HOMOGENEITY, THE FREE MOVEMENT OF PERSONS AND INTEGRATION WITHOUT MEMBERSHIP: MISSION IMPOSSIBLE?
}

\begin{abstract}
Matthew Jay*
Summary: This article provides a detailed legal comparison of the free movement and residence rights, including mutual recognition of qualifications and social security coordination, accorded to nationals of the four EFTA States: Norway, Iceland, Liechtenstein and Switzerland. The first half considers the extent to which the EEA Agreement, which relates to the former three countries, secures homogeneity in this area of law; and the second half of the article looks at the EU-Swiss framework for the same purposes. It concludes that the EEA framework, through the activism of its Court, goes a long way to securing homogeneity - to the extent of equating nationality of an EEA-EFTA state with Union citizenship, at least for the purposes of movement and residence. The Swiss model, however, still mirrors free movement law prior to Directive 2004/38 and even though part of the same internal market as the EEA, the Swiss framework does very little for the market's homogeneity.
\end{abstract}

\section{Introduction}

Export of the acquis communautaire to third countries occurs in a variety of ways ${ }^{1}$ with the result that the internal market operates not just with two speeds, but with many. ${ }^{2}$ Some methods are more effective at achieving a homogenous area of free trade and movement than oth-

\footnotetext{
Adviser and Caseworker, Citizens Advice Bureau, Great Ormond Street Hospital for Children.

1 S Blockmans and A Łazowski (eds), The European Union and Its Neighbours (TMC Asser Press 2006); A Łazowski, 'Enhanced Multilateralism and Enhanced Bilateralism: Integration without Membership in the European Union' (2008) 54 CML Rev 1433; A Magen, 'Transformative Engagement Through Law: The Acquis Communautaire as an Instrument of EU External Influence' (2007) 9 European Journal of Law Reform 361; R Petrov, 'Exporting the Acquis Communautaire into the Legal Systems of Third Countries' (2008) European Foreign Affairs Review 331; F Maiani, R Petrov and E Mouliarova (eds), 'European Integration without EU Membership: Models, Experiences, Perspectives' (2009) EUI Working Paper MWP No 2009/10.

2 C Ehlermann, 'How Flexible is Community Law? An Unusual Approach to the Concept of "Two Speeds"' (1984) 82 Michigan Law Review 1275; S Blockmans and S Prechal, 'The European Integration Process: A Continuum of "Deepening" and "Widening"' in S Blockmans and S Prechal (eds), Reconciling the Deepening and Widening of the European Union (TMC Asser Press 2006) 8-9.
} 
ers and this can be seen particularly with the free movement of persons among the EU and the European Free Trade Association (EFTA) States. This article presents an in-depth legal survey of the free movement of persons under two quite distinct regimes and comments on the extent to which these systems support or threaten the homogeneity of the internal market. Section 2 considers the European Economic Area (EEA), and Section 3, the Swiss bilateral framework. The reader will see how dramatic the legal differences between these two systems are. In the former, nationality of one of the EEA-EFTA States is almost equated to Union citizenship, which contributes to favourable conditions for achieving legal homogeneity, as well as presenting a legal dilemma: a reading of citizenship into an Agreement devoid of citizenship. In the EU-Swiss framework, the Swiss commitment to sovereignty has produced a rusty machine which does not connect well with its EEA counterpart - albeit one which does continue to function.

Two important caveats are needed: first, this paper is a legal comparative study between the two systems. Both have very different political contexts, which are commented on, but which it is beyond this article to explore fully. Secondly, it has not been possible to assess how the two systems operate at the domestic level in the EU or EFTA States.

\section{The European Economic Area}

\subsection{The EEA Agreement}

The EEA Agreement ${ }^{3}$ came into force on 1 May 1994. It was intended to be an agreement between the then EFTA States of Austria, Finland, Iceland, Norway, Sweden and Switzerland, on the one hand, and the European Communities and their Member States on the other. However, the Swiss voters rejected it in a referendum, as a consequence of which Switzerland's application for EU membership was suspended ${ }^{4}$ and she

\footnotetext{
3 Agreement on the European Economic Area [1994] OJ L1/3. What is presented here is a basic outline. For more comprehensive analyses of the Agreement, see, inter alia, Łazowski, 'EEA Countries' in Blockmans and Łazowski (n 1); Łazowski, 'Enhanced Multilateralism' (n 1); S Norberg and others, The European Economic Area. EEA Law. A Commentary on the EEA Agreement (Kluwer 1993); C Tobler, 'Internal Market Beyond the EU: EEA and Switzerland' (Directorate-General for Internal Policies Briefing Paper) (2010) IP/A/IMCO/NT/2009-13 PE 429.993; P-C Müller-Graff and E Selvig (eds), EEA-EU Relations (Arno Spitz 1999); T von Stiphout, 'Homogeneity vs Decision-Making Autonomy in the EEA Agreement' (2007) 9 European Journal of Law Reform 431; T-I Harbo, 'The European Economic Area Agreement: A Case of Legal Pluralism' (2009) 78 Nordic Journal of Interational Law 201. For a study into the effectiveness of EEA law, see M Méndez-Pinedo, EC and EEA Law (Europa Law Publishing 2009). The President of the EFTA Court, Carl Baudenbacher, writes extensively on the Court's work. An overview of its case law is presented in C Baudenbacher, EFTA Court - Legal Framework and Case Law (3 ${ }^{\text {rd }}$ edn, EFTA Court 2008).

4 Commission (EC) 'Future relations with Switzerland' (Communication) COM (93) 486 final, 1 October 1993, 1.
} 
entered into the series of bilateral arrangements discussed below. Austria, Finland and Sweden joined the EU the year after the Agreement came into force, that being the same year Liechtenstein joined the Agreement. Thus, today, the EEA Agreement is between three of the four EFTA States (Liechtenstein, Iceland and Norway - Switzerland is still a member of EFTA), on the one hand, and the EU and its twenty-seven Member States on the other. ${ }^{5}$

Article 1 makes clear that the Agreement aims to extend the internal market to the EEA-EFTA States. The main part of the Agreement copies some Treaty provisions ${ }^{6}$ and refers to a series of Annexes which contain secondary Union legislation. All incorporated acts are read with the horizontal adaptations found in Protocol 1 to the Agreement, or more specific adaptations found in the Annexes. No mechanism exists to update the main body (and this has not been done, even with subsequent Treaty amendments, including Lisbon) but Articles 98-104 EEA stipulate that the EEA Joint Committee (JC) shall take a decision on amending the Annexes as relevant. Especially important for the implementation of Union law are Article 7 EEA, by which Acts referred to in the Annexes are binding on the Parties and are to be made part of their internal legal orders; ${ }^{7}$ Article 3, the loyal cooperation clause which obliges states to take all necessary measures to fulfil their obligations under the Agreement; and Protocol 35, whereby the Contracting Parties agree to enact a measure whereby implemented EEA measures take precedence over national rules.

It should be emphasised here that the EEA-EFTA States must nonetheless amend their laws for any EU measure to come into force. No legal sovereignty is ceded to the EU. ${ }^{8}$ Additionally, the EEA-EFTA States'

5 Łazowski, 'EEA Countries' (n 3) 96-103.

6 As they stood before the Maastricht Treaty.

7 Acts corresponding to Regulations 'shall as such be made part of the internal legal order of the Contracting Parties'; acts corresponding to Directives 'shall leave to the authorities of the Contracting Parties the choice of form and method of implementation' (Article 7(a)-(b) EEA). This echoes Article 288 TFEU.

8 The sole article of Protocol 35 reads: 'For cases of possible conflicts between implemented EEA rules and other statutory provisions, the EFTA States undertake to introduce, if necessary, a statutory provision to the effect that EEA rules prevail in these cases'. As the preamble to the Protocol makes clear, 'the Agreement aims at achieving a homogenous European Economic Area, based on common rules, without requiring any Contracting Parties to transfer legislative powers' to the EEA. Therefore, legislative homogeneity 'will have to be achieved through national procedures'. It is questionable whether it is truly possible to achieve homogeneity in such a system. Unfortunately, a study into the actual application of EEA law in the EEA-EFTA States is far beyond the scope of this paper, but it should be noted that the three EEA-EFTA States have transposed Directives 2004/38 and 2005/36 (on mutual recognition of qualifications) into national law to the satisfaction of the EFTA Surveillance Authority. This information is available on the ESA website: 'EFTA Surveil- 
consent, in the EEA $\mathrm{JC}$, is required before EU measures are implemented into the Annexes. ${ }^{9}$ As will be seen below, this has led to delays and could lead to the non-implementation of key legislation, though in most cases the EEA-EFTA States are more integrationist than many EU States. ${ }^{10}$

Homogeneity is also secured by the EFTA Court ${ }^{11}$ and the EFTA Surveillance Authority (ESA), which were created by the EFTA Surveillance Agreement (ESAg). ${ }^{12}$ These, and their procedures, such as the advisory and infraction procedures, are modelled very much on the Commission, the ECJ and the analogous preliminary reference and infraction procedures. ${ }^{13}$ By Article 6 EEA and Article 3(1) ESAg, provisions of the EEA Agreement which correspond to EU provisions shall in their implementation and application be interpreted in conformity with the relevant rulings of the [ECJ] given prior to the date of signature [2 May 1992] of this Agreement'. For post-signature ECJ case law, Article 3(2) ESAg stipulates that in the interpretation of the agreement, the ESA and the EFTA Court 'shall pay due account to the principles laid down by the relevant rulings by the [ECJ]'. However, as will be seen, while this distinction has constitutional implications, the reality is that the EFTA Court will usually follow the ECJ's jurisprudence, even where it is not legally bound to do so.

lance Authority Implementation status database' <http://www.eftasurv.int/internal-market-affairs/implementation-status-/> accessed 12 March 2012. Indeed, as the 2010 EEA Joint Committee Annual Report points out, according to the ESA's Internal Market Scoreboard, the transposition deficit for the EEA-EFTA countries is the lowest in Europe, averaging $0.6 \%$, as opposed to $0.9 \%$ for the EU Member States. European Economic Area Joint Committee, Annual Report of the EEA Joint Committee 2010. The Functioning of the EEA Agreement (2011) Ref 1103725 [5].

9 This is subject to the dispute resolution procedure in EEA, art 102.

10 See above, $\mathrm{n} 8$.

11 C Baudenbacher and others (eds), The EFTA Court Ten Years On (Hart 2005); C Baudenbacher, 'The EFTA Court and the European Court' in P-C Müller-Graff and E Selvig (n 3); V Kronenberger, 'Does the EFTA Court Interpret the EEA Agreement As If It Were the EC Treaty? Some Questions Raised by the Restamark Judgment' (1996) 45 ICLQ 198; H Fredriksen, 'The EFTA Court 15 Years On' (2010) 59 ICLQ 731.

12 Agreement Between the EFTA States on the Establishment of a Surveillance Authority and a Court of Justice [1994] OJ L344/3. ESAg art 4 created the Surveillance Authority, and ESAg art 27, the EFTA Court.

13 ESAg art 31 supplies the analogous infraction procedure and art 34 provides for an 'advisory opinion', which resembles a preliminary reference procedure. The most striking differences between these procedures and their EU counterparts is that the EFTA Court has no power to impose financial penalties for infractions and that its advisory opinions are not binding on the referring court. An action for annulment is laid down in ESAg art 36. 


\subsection{Free movement and residence rights}

The EEA provisions relating to the free movement of persons are found in Part III, Chapters I and II, with the first Chapter dealing with the movement of workers and the second, the right of establishment. ${ }^{14}$ The EU secondary legislation in this area comes under Annexes V (workers), VI (social security), VII (mutual recognition of qualifications) and VIII (establishment). This section (2.2) considers the primary and secondary provisions on the right to move and reside. The next four deal with mutual recognition of qualifications (2.3), social security coordination (2.4), transitional provisions (2.5) and the future prospects of the agreement in light of this discussion (2.6).

With some minor exceptions, Article 28 EEA corresponds exactly with Article 45 TFEU. References to the Union are instead references to EC Member States and EFTA States; ${ }^{15}$ the last sentence in paragraph 3(d) TFEU is omitted; ${ }^{16}$ and paragraph 5, which makes reference to Annex V of the Agreement, is added. Article 31 EEA on the freedom of establishment corresponds to Article 49 TFEU and makes reference to Annexes VIII to XI.

Annex V refers to Regulation $1612 / 68,{ }^{17}$ as amended by other EU acts and as adapted for the EEA Agreement and 'the act referred to in point 3 of Annex VIII', namely, Directive 2004/38, ${ }^{18}$ as adapted. The Annex also refers to Regulation 635/2006, ${ }^{19}$ which repealed Regulation

\footnotetext{
14 The establishment of companies and the freedom to move to provide and receive services are not considered in this paper.

15 The reference to 'EFTA States' is somewhat of a misnomer. Switzerland is an EFTA State but is not a party to the EEA Agreement.

16 Because the secondary legislation 'to be drawn up by the Commission' to which Article 45(3)(d) TFEU refers is already embodied in the EEA Agreement's Annexes. Norberg and others (n 3) 409.

17 Council Regulation (EEC) 1612/68 on freedom of movement for workers within the Community [1968] OJ L257/2.

18 Parliament and Council Directive 2004/38/EC on the right of citizens of the Union and their family members to move and reside freely within the territory of the Member States amending Regulation (EEC) No 1612/68 and repealing Directives 64/221/EEC, 68/630/ EEC, 72/194/EEC, 73/148/EEC, 75/34/EEC, 75/35/EEC, 90/364/EEC, 90/365/EEC and 93/96/EEC [2004] OJ L158/77.

19 Commission Regulation (EC) 635/2006 repealing Regulation (EEC) No 1251/70 on the right of workers to remain in the territory of a Member State after having been employed within that state [2006] OJ L112/9. It is interesting that this has been incorporated at all. The sole purpose of Regulation 635/2006 was to repeal Regulation 1251/70. It is not clear why Point 4 of the Annex (whereat Regulation 1251/70 was referred to) was not simply deleted. Preambular recital 7 to Decision 158/2007 (n 25, below) states simply that the later Regulation repealed the earlier, which was incorporated into the Agreement, and which is consequently to be repealed under the Agreement. Perhaps this is just a gesture towards homogeneity and a clear message that the old law had been repealed.
} 
$1251 / 70,{ }^{20}$ and to Directive $77 / 486,{ }^{21}$ and Commission Decision $2003 / 8^{22}$ - all three without adaptation.

\subsubsection{Regulation 1612/68 and Regulation 492/2011}

Regulation 492/2011 ${ }^{23}$ recasts Regulation 1612/68. The former has yet to be incorporated into the EEA Agreement so, until it is, different measures will apply in the EU and EEA frameworks. But because the new Regulation merely codifies the old and because of certain adaptations made by the Annex, this produces no disparity between the rights conferred on EU and EEA-EFTA nationals. ${ }^{24}$

Under Annex V, Articles 40, 41, 42(1) and 48 of Regulation 1612/68 do not apply and Article 42(2) is adapted so that instead of referring to what was Article 51 EEC, it refers to Article 29 EEA. Articles 40 and 41 of Regulation 1612/68 were not re-enacted in Regulation 492/2011; and Article 48 repealed Regulation 38/64 (which was never incorporated into the Annex) and refers to the direct applicability of the Regulation and so has no EEA relevance. The only major difference between Regulation 1612/68 as adapted for the EEA Agreement and Regulation 492/2011 is that old Article 42(1) does not apply in the former, whereas it stills forms part of Regulation 492/2011 as Article 36(1). However, the new Article no longer refers to provisions of the defunct ECSC Treaty but states solely that the Regulation shall not affect the provisions of the Euratom Treaty which deal with the eligibility for skilled employment in the nuclear energy sector. As none of the EFTA States is party to Euratom, this provision has no relevance either. Legislative homogeneity is achieved as far as these Regulations are concerned, notwithstanding the enactment of Regulation 492/2011.

\subsubsection{Directive $2004 / 38$ and Union citizenship}

Directive 2004/38 is adapted to fit with the terminology and operation of the EEA framework. ${ }^{25}$ According to points 3(b) and (c) of Annex

\footnotetext{
20 Commission Regulation (EEC) $1251 / 70$ on the right of workers to remain in the territory of a Member State after having been employed in that State [1970] OJ L142/24.

21 Council Directive $77 / 486 /$ EEC on the education of the children of migrant workers [1977] OJ L199/32.

22 Commission Decision 2003/8/EC implementing Council Regulation (EEC) No 1612/68 as regards the clearance of vacancies and applications for employment [2003] OJ L5/16.

23 Parliament and Council Regulation (EU) 492/2011 on freedom of movement for workers within the Union [2011] OJ L141/1.

24 This is subject to the limited pre- and post-signature case-law distinction.

25 Directive 2004/38 was incorporated into the EEA Agreement by JC Decision 158/2007 amending Annex V (Free movement of workers) and Annex VIII (Right of establishment) of the EEA Agreement [2008] OJ L124/20.
} 
VIII, instead of referring and applying to Union citizens, the Directive is to be read as referring to nationals of the 'EC and EFTA States'; and per point 3(d) of Annex VIII, in Article 24(1) of the Directive, the word 'Treaty' is to be read as '[EEA] Agreement' and the words 'secondary law' as 'secondary law incorporated in the Agreement'. The entirety of Directive 2004/38 is thereby incorporated into the EEA Agreement. ${ }^{26}$

Directive 2004/38 is sometimes known as the 'Citizens' Rights Directive'27 or 'Citizenship Directive'28 and, although only 'relevant to the extent necessary for the proper interpretation and application of the Agreement', ${ }^{29}$ of the 31 recitals of the Directive's Preamble, only eight make no explicit reference to Union citizenship. Admittedly, most of these references could be easily replaced by 'EC and EFTA nationals' or something similar, but it is impossible to escape the underlying theme. The very first recital recalls that '[c]itizenship of the Union confers on every citizen of the Union a primary and individual right to move and reside freely' and the third that, echoing the case- law of the ECJ, in particular Grzelczyk, ${ }^{30}$ "citizenship should be the fundamental status of nationals of the Member States ... It is therefore necessary to codify and review the existing Community instruments ... in order to simplify and strengthen the right of free movement and residence of all Union citizens [emphasis added]'. It is further recalled that the 'fundamental and personal right of residence' is conferred directly on Union citizens by the Treaty $^{31}\left(11^{\text {th }}\right.$ recital) and that the permanent residence of Union citizens 'would strengthen the feeling of Union citizenship and is a key element in promoting social cohesion, which is one of the fundamental objectives of the Union' (17 $17^{\text {th }}$ recital).

The wholesale incorporation of Directive 2004/38 creates an anomaly and highlights tension between the static nature of the Agreement, which contains no provisions as to citizenship, and the EU trend of strengthening free movement and residence rights with (EU) citizenship. As the EEA Agreement was modelled on the EC Treaty, and was not amended following Maastricht, Amsterdam, Nice or Lisbon, citizenship rights, as defined in the Directive, are granted to persons who are em-

${ }^{26}$ See $\mathrm{n} 8$ for the Directive's implementation status at national level in the EEA-EFTA States.

27 C Barnard, The Substantive Law of the EU ( $3^{\text {rd }}$ edn, OUP 2010) 424.

28 R White, 'The New European Social Security Regulations in Context' (2010) 17 Journal of Social Security Law 144, 147.

29 Protocol 1 to the EEA Agreement, point 1.

30 Case C-184/99 Rudy Grzelczyk v Centre Public d'Aide Sociale d'Ottignies-Louvain-laNeuve [2001] ECR I-6193 [31]: 'Union citizenship is destined to be the fundamental status of nationals of the Member States'.

31 Namely, TFEU, art 20. 
phatically not Union citizens. The Contracting Parties entered a joint declaration to JC Decision 158/2007 to the effect that, inter alia, Union citizenship and general political rights do not form part of the EEA Agreement (though this declaration 'shall be without prejudice to the evaluation of the EEA relevance of future EU legislation as well as future case law of the European Court of Justice based on the concept of Union Citizenship'). ${ }^{32}$ Writing about the Agreement more generally, and noting the lack of any procedure to amend the EEA text, Bruzelius predicts that this may cause it to 'disintegrate' as the gaps between the EU and EEA rules widen further and further. ${ }^{33}$ She points out that it is very much down to the EFTA Court to interpret the provisions of the Agreement to produce a harmonious effect. It will be seen how far the EFTA Court's integrationist stance goes in this area of law.

The EFTA Court has proved instrumental in achieving a harmonious result for the EEA generally. Fredriksen ${ }^{34}$ has shown how the EFTA Court early on rejected arguments, such as those advanced by an initially sceptical ECJ, ${ }^{35}$ and commentators such as Cremona, ${ }^{36}$ that the EEA Agreement does not, or cannot, create a homogenous system. Although the EFTA Court has noted that having two courts - the EFTA Court on one side, the ECJ on the other - may sometimes lead to different interpretations of the same provision, ${ }^{37}$ it has managed to ensure the possibility of the project. The Court ensured the direct effectiveness of EEA provisions where they have been implemented into national law in line with Protocol 35 to the EEA Agreement, ${ }^{38}$ and read into the Agreement a Francovich-style principle of state liability ${ }^{39}$ to pay compensation in respect of faulty or non-implementation of EEA-incorporated EU measures. ${ }^{40}$ It also challenged the ECJ's early opinion that the Agreement does not go as far as the EU in integration by consistently rejecting such arguments in a line of cases and setting the "threshold for divergent interpretations

\footnotetext{
32 JC Decision 158/2007 [2008] OJ L124/20, 23.

33 K Bruzelius 'The Impact of EU Values on Third Countries' National Legal Orders: EU Law as a Point of Reference in the Norwegian Legal System' in Maiani, Petrov and Mouliarova (n 1) 88.

34 Fredriksen (n 11).

35 Opinion 1/91 [1991] ECR I-6079, and Opinion 1/92 [1992] ECR I-2821.

36 M Cremona, 'The "Dynamic and Homogenous" EEA: Byzantine Structures and Various Geometry' (1994) 19 EL Rev 508.

37 Joined Cases E-9/07 and 10/07 L'Oréal Norge AS [2008] EFTA Ct Rep 259 [27]; Fredriksen (n 11) 740-743.

38 See $n 8$.

39 Joined Case C-6/90 and C-9/90 Francovich and Others [1991] ECR I-5357.

40 Case E-9/97 Erla María Sveinbjörnsdóttir v Iceland [1998] EFTA Ct Rep 95.
} 
... even higher.'41 Importantly, the Court takes an 'integration-friendly' approach. ${ }^{42}$ It has also been demonstrated that the dialogue between the EFTA Court, the ECJ and its Advocates-General is very constructive, to the extent that Vassilios Skouris, the ECJ's President, calls it a 'Paradigm for International Cooperation'. ${ }^{43}$ The EFTA Court will, of course, rely on ECJ judgments, but it has also relied on Advocates-General, even where their opinions differ from those of the ECJ. Likewise, AdvocatesGeneral and, most happily for the homogeneity of the internal market, the ECJ, on occasion, follow the EFTA Court. ${ }^{44}$

To date, only two cases before the EFTA Court have dealt with either Regulation 1612/68 or Directive 2004/38. The first concerned the Regulation and was patently inadmissible from the outset. ${ }^{45}$ The second, concerning the Directive, was Case E-4/11 Arnulf Clauder. ${ }^{46}$

Mr Clauder, a German national, moved to Liechtenstein in 1992 where he initially resided as the spouse of a worker, his first wife, who was also a German national. He was granted a permanent residence permit in $2002^{47}$ and in 2009 he divorced. In 2010, he remarried another German national who, at the time, was resident in Germany. Mr Clauder applied under national law for a family reunification permit but this was denied. He was retired, and, in addition to his pensions in Germany and Liechtenstein, was receiving supplementary benefits. ${ }^{48}$ If his wife were to move to Liechtenstein, his benefit entitlement would increase, even if she undertook paid employment. ${ }^{49}$ The Liechtenstein Administrative Court referred the following question to the EFTA Court: ${ }^{50}$

\footnotetext{
${ }^{41}$ Fredriksen (n 11) 740-743.

42 ibid 740-750; Kronenberger (n 11).

43 V Skouris, 'The ECJ and the EFTA Court under the EEA Agreement: A Paradigm for International Cooperation between Judicial Institutions' in Baudenbacher, The EFTA Court Ten Years On (n 11).

${ }_{44}$ C Baudenbacher, 'The EFTA Court, the ECJ and the Latter's Advocates General - A Tale of Judicial Dialogue' in A Arnull, P Eeckhout and T Tridimas (eds), Continuity and Change in EU Law: Essays in Honour of Sir Francis Jacobs (OUP 2008) and Baudenbacher, 'The EFTA Court and the European Court' (n 11).

45 Case E-3/94 Alexander Flandorfer Friedmann and others $v$ Austria [1994] EFTA Ct Rep 83.

46 Case E-4/11 Arnulf Clauder [2011] EFTA Ct Rep 216. Reference is made to both the report of the hearing and the judgment. These are available at <http://www.eftacourt.int/ index.php/cases/arnulf_clauder $1>$ accessed 12 March 2012.

47 Liechtenstein is subject to special provisions relating to residence permits: see section 2.5 below.

48 There was a question as to whether these were social assistance within the meaning of the Directive or whether they were non-contributory social security benefits within the meaning of Regulation 1408/71. The ESA preferred the latter ([63] of the report of the hearing) but the Court did not decide the matter.

49 Report of the hearing (n 46) [1]-[25] and judgment (n 46) [11]-[18].

50 Hearing, ibid [25], judgment, ibid [18].
} 
Is Directive 2004/38/EC, in particular Article 16(1) in conjunction with Article $7(1)$, to be interpreted such that a Union citizen with a right of permanent residence, who is a pensioner and in receipt of social welfare benefits in the host Member State, may claim the right to family reunification even if the family member will also be claiming social welfare benefits?

Article 16 of the Directive grants Union citizens, and in this context EEA-EFTA nationals, permanent residence in the host state once they have completed five years' lawful residence, subject to some conditions relating to prolonged absences; this also applies to family members ${ }^{51}$ who have lawfully resided with the citizen for five years in the host state. The conferral of these rights is not contingent on the conditions set out in Chapter III of the Directive, namely the conditions of economic selfsufficiency or worker or self-employed status found in Article 7(1)(a)-(c). In contrast, for residence between three months and five years, the citizen must fulfil one of these criteria and, if he does, his family members may join and reside with him. ${ }^{52}$

In Clauder, it was not disputed that Mr Clauder had the right of permanent residence. The arguments of the Liechtenstein, Dutch and Danish governments ${ }^{53}$ were that it was a deliberate legislative choice to exclude from Article 16 family members who did not meet the self-sufficiency criteria. In other words, that Mrs Clauder derived no rights from the fact that Mr Clauder had acquired permanent residence. Were she to join her husband, their claims for social assistance would increase and they would become a burden on the welfare system in Liechtenstein. ${ }^{54}$

The EFTA Court rejected such an interpretation and preferred, instead, that put forward by Mr Clauder, ESA and the Commission. Article 16 of the Directive was intended to be the highest level of rights conferred under a Directive which was designed to "strengthen the right of free movement and residence” of EEA nationals'. ${ }^{55}$ The Court first held that

\footnotetext{
51 'Family members' for the purposes of the Directive are defined in Directive 2004/38 art 2(2) as: (a) the spouse; (b) a registered partner where the host treats these as equivalent to marriage; (c) the direct descendants under the age of 21 and dependent direct descendants of the citizen or the spouse or partner; and (d) the dependent ascendant relatives of the citizen or the spouse or partner.

52 ibid art $7(1)(d)$.

53 The submissions of the Liechtenstein and Dutch governments are summarised, along with those of the complainant, the EFTA Surveillance Authority and the Commission, in the report of the hearing ( $\mathrm{4}$ 46) [27]-[76]. Those of Denmark only appear, grouped with the other governments, in the judgment (n 46) at [28]-[32].

54 As the Netherlands pointed out, should she take up work or self-employed activity, she would fall within Article 7(1)(a) and acquire a free-standing right of residence.

55 Judgment (n 46) [33], quoting recital 3 of the Preamble to the Directive.
} 
Article 16 gives family members derived rights by virtue of their being a family member of, and residing with, the EEA national. This is not an autonomous right until that family member has been resident for five years. Secondly, Article 16 is not subject to the conditions of self-sufficiency and this is a change from the previous law, where there was a general condition of sufficient resources (now, there is only such a condition in certain specified areas). Because Article 16 gives derived rights to family members, it must be presumed prima facie that the derived right, also, is not so subject. ${ }^{56}$ Accordingly, because Mr Clauder already had a right of permanent residence, Mrs Clauder was entitled to join him under a derived right of residence, this right being free from any conditions as to self-sufficiency. ${ }^{57}$

The active, pro-integrationist stance of the EFTA Court can readily be seen in this judgment. None of the parties put forward any arguments based on the fact that the Directive confers citizenship rights and therefore ought not to be interpreted as expansively in what is, according to the joint declaration to JC Decision 158/2007, a non-political extension of the internal market. And the Court did not, of course, base its decision on any such arguments: quite the contrary, for the judgment makes several references to the promotion and strengthening of free movement rights. ${ }^{58}$ The Court also followed the ECJ case of Sturgeon, ${ }^{59}$ for the principle that "where a provision of EEA law is open to several interpretations, preference must be given to the interpretation which ensures that the provision retains its effectiveness'. ${ }^{60}$ Finally, with the support of another ECJ case, Metock, ${ }^{61}$ reliance was placed on arguments that the Directive was to promote the rights of EEA nationals and their family members to move and reside freely and that, even before Directive 2004/38, the legislature 'recognised the importance of ensuring the protection of the family life of nationals of the EEA States in order to eliminate obstacles to the exercise of the fundamental freedoms guaranteed by EEA law'. ${ }^{62}$ The fact that citizenship and political rights form no part of the EEA Agreement did not in any way deter the EFTA Court, the ESA or the Commission from their arguments.

\footnotetext{
56 ibid [47].

57 And it was therefore unnecessary to deal with the second and third questions, which were whether it was relevant to the first question that the person with a right of permanent residence was economically active or whether the family member would be employed or selfemployed. Hearing (n 46) [25], judgment, ibid [18].

58 In particular, judgment, ibid [33]-[37].

59 Joined Cases C-402/07 and C-432/07 Sturgeon and others [2009] ECR I-10923.

60 ibid [48].

61 Case C-127/08 Metock and others [2008] ECR I-6241.

62 Arnulf Clauder judgment (n 46) [34]-[35].
} 
It is also noteworthy that not only did the EFTA Court refer to Article $8(1)$ of the European Convention on Human Rights (ECHR) ${ }^{63}$ to support its conclusions (relying on its own case law to the effect that the EEA Agreement is to be interpreted in light of fundamental rights), it also referred to the same right as protected under Article 7 of the EU Charter of Fundamental Rights. ${ }^{64}$ Reliance on ECHR is unproblematic, as the EEAEFTA States are states parties to it. The EU Charter presents another legal difficulty, however. The Charter was given 'the same legal value as the Treaties' by Article 6(1) TEU following the Lisbon Treaty ${ }^{65}$ but, as with other EU treaty amendments, the Charter has not made its way into the EEA Agreement. Although the EFTA Court only 'noted' Article 7 of the EU Charter as well as Article 8 ECHR, this can be seen as another example of the Court trying to secure the homogeneity of substantive rights in the free movement context and within the EEA generally. More importantly, it shows that the EFTA Court does not consider the EEA Agreement to be entirely economic. The Agreement may not grant political rights in the nature of voting and consular protection, but it recognises the need, at the very least, to respect human rights.

This raises the question of how accurate the joint declaration is, and how accurate it is to say that citizenship rights do not form part of the EEA Agreement. It is suggested that the EFTA Court has essentially assimilated nationality of one of the EEA-EFTA States with EU citizenship for the purposes of free movement and residence. ${ }^{66}$ No other conclusion is tenable if the homogeneity of the internal market is to be maintained in a manner which secures fair and effective legal rights, though this can be seen to come at the cost of legal certainty. It was recognised very early on that the Agreement does go beyond simple market integration and confers rights, such as non-discrimination, aiming to improve living standards and working conditions. ${ }^{67}$ Further, Fredriksen has shown how the EFTA Court has minimised the differences between EEA and EU law, has consistently rejected the EFTA States' signature preconditions that the Agreement should in particular cases derogate from EU law and has rejected all attempts by EEA-EFTA States to increase their political leverage. ${ }^{68}$ Finally, it is White's argument, in the context of so-

\footnotetext{
${ }_{63}$ Convention for the Protection of Human Rights and Fundamental Freedoms (European Convention on Human Rights) art 8(1): the right to private home and family life.

64 Arnulf Clauder judgment (n 46) [49].

65 P Craig and G de Búrca, EU Law (5 $5^{\text {th }}$ edn, OUP 2011) 394.

66 As already stated, it is not suggested that the Court has gone beyond this. It would simply be impossible for the Court to grant the list of rights in TFEU art 20(2) to EEA-EFTA nationals.

67 Norberg and others (n 3) 403.

68 Fredriksen (n 11) 736-747.
} 
cial security coordination, that citizenship-compliant interpretations will increasingly be the norm in the ECJ. ${ }^{69}$ The EFTA Court's judgment in Arnulf Clauder is a step towards greater integration and ensures the effet utile of the Citizenship Directive in the EEA. Because citizenshipcompliant interpretations have not been expressly mandated by the Contracting Parties, however, a question is raised as to how far this will go and whether EEA-EFTA nationals really can benefit explicitly from ECJ case law on citizenship.

\subsection{Mutual recognition of qualifications}

Article 30 EEA providing for the mutual recognition of diplomas, certificates and other evidence of formal qualifications corresponds to Article 53 TFEU - except that the second paragraph of the latter, stipulating that 'the progressive abolition of restrictions' concerning the medical and allied and pharmaceutical professions 'shall be dependent upon coordination of the conditions for their exercise in the various Member States', is not reproduced. Reference is made to Annex VII of the Agreement.

Originally, Annex VII referred to thirty pages of legislation on mutual recognition of qualifications as adapted for the EEA. This was almost entirely replaced by JC Decision 142/2007. ${ }^{70}$ The main section of the Annex is now divided into three parts: a general system, recognition of professional experience and automatic experience; legal professions; and commerce and intermediaries. Directive $2005 / 36^{71}$ is the bulk of the first part and amendments to the Directive by one subsequent Directive and four Regulations have been incorporated by a series of further Decisions. ${ }^{72}$ Article 9(e) of Directive 2005/36 does not apply ${ }^{73}$ and the Directive is adapted so that the EEA-EFTA States are duly accounted for. The

\footnotetext{
69 See notes 95-98 below.

70 EEA JC Decision 142/2007 amending Annex VII (Mutual recognition of qualifications) and Protocol 37 to the EEA Agreement [2008] OJ L100/70.

${ }^{71}$ Parliament and Council Directive 2005/36/EC on the recognition of professional qualifications [2005] OJ L255/22.

72 Directive 2006/100 [2006] OJ L363/141 was incorporated with Directive 2005/36 by JC Decision 142/2007; Regulation 1430/2007 [2007] OJ L320/3 by JC Decision 50/2008 [2008] OJ L223/47; Regulation 755/2008 [2008] OJ L205/10 by JC Decision 127/2008 [2009] OJ L25/33; Regulation 279/2009 [2009] OJ L93/ 11 by JC Decision 95/2009 [2009] OJ L304/6; and Regulation 213/2011 [2011] OJ L59/4 by Decision 134/2011 [2012] OJ L76/19.

73 This relates to the requirement of the provision of information to recipients of services where the service provider performs an activity subject to VAT. Article 9(e) stipulates that Member States may require service providers to furnish the VAT identification number referred to in Article 22(1) of Directive 77/388, which does not form part of the EEA Agreement.
} 
only other measure falling under the first part is Commission Decision $2007 / 172$ setting up the group of coordinators for the recognition of professional qualifications. ${ }^{74}$

The second part, dealing with legal professions, contains Directive $77 / 249^{75}$ and Directive 98/5. ${ }^{76}$ The final part of the Annex contains two Directives on toxic products ${ }^{77}$ and one on self-employed commercial agents. ${ }^{78}$ Additionally, there is one act of which the parties shall take note: Recommendation 89/601 concerning the training of health personnel in the matter of cancer. ${ }^{79}$ These are all without any major adaptations. ${ }^{80}$

\subsection{Social security coordination}

Social security co-ordination is an 'inherently complex'81 area of law which has been developing in the EU for over fifty years. ${ }^{82}$ After some delay, ${ }^{83}$ Regulation $883 / 2004^{84}$ and its implementation Regulation $987 / 2009^{85}$ are now the scheme currently employed under Annex

74 Commission Decision 2007/172/EC setting up the group of coordinators for the recognition of professional qualifications [2007] OJ L79/38. The EEA-EFTA States may appoint persons to act as observers at the meetings of the group of coordinators.

75 Council Directive $77 / 249$ /EEC to facilitate the effective exercise by lawyers of freedom to provide services [1977] OJ L78/17.

76 Parliament and Council Directive 98/5/EC to facilitate practice of the profession of lawyer on a permanent basis in a Member State other than that in which the qualification was obtained [1998] OJ L77/36.

77 Council Directive 74/556/EEC laying down detailed provisions concerning transitional measures relating to activities, trade in and distribution of toxic products and activities entailing the professional use of such products including activities of intermediaries [1974] OJ L307/1 and Council Directive 74/557/EEC on the attainment of freedom of establishment and freedom to provide services in respect of activities of self-employed persons and of intermediaries engaging in the trade and distribution of toxic products [1974] OJ L307/5.

78 Council Directive 86/653/EEC on the coordination of the laws of the Member States relating to self-employed commercial agents [1986] OJ L382/17.

79 Commission Recommendation 89/601/EC concerning the training of health personnel in the matter of cancer [1989] OJ L346/1.

80 Directive $77 / 249$ and Directive $98 / 5$ are adapted so that the Icelandic, Liechtenstein and Norwegian words for 'Lawyer' are added to Article 1(2) of both. Directive 74/557 is adapted so as to include in its Annex certain chemicals to which separate national provisions apply in Liechtenstein and Norway.

81 White (n 28) 148.

82 ibid 144.

83 The new Annex entered into force on 1 June 2012.

84 Parliament and Council Regulation (EC) 883/2004 on the coordination of social security systems [2004] OJ L166/1.

85 Parliament and Council Regulation (EC) 987/2009 laying down the procedure for implementing Regulation (EC) No 883/2004 on the coordination of social security systems [2009] OJ L284/1. 
VI EEA. This is the scheme which operates in the EU, with Regulation $1408 / 71^{86}$ and its implementing Regulation $574 / 72^{87}$ having been replaced. The entire Annex was replaced by a two-part Annex by JC Decision 76/2011.88 Part I deals with general social security coordination. Regulation 883/2004, as amended by Regulation 988/200989 and Regulation $1244 / 2010,{ }^{90}$ applies and is read with country-specific adaptations to the annexes of the Regulation and one other minor adaption to Article 87(10), which deals with transitional provisions: that, as regards Liechtenstein, the second sentences of Article 65(2) and (3) shall be applicable at the latest from 1 May 2012. These provisions deal with wholly unemployed persons who reside in a Member State other than the competent State. Implementing Regulation 987/2009 is incorporated only with country-specific additions to the Regulation's annexes. Part II of Annex VI concerns the safeguarding of supplementary pension rights and retains Directive 98/49 on safeguarding the supplementary pension rights of employed and self-employed persons. ${ }^{91}$

Under the Annex as it previously stood, Regulation 1408/71 was incorporated, as amended, updated and adapted. The third subparagraph of Article 1(j) did not apply. This defined 'legislation' for the purposes of the Regulation and the second subparagraph stated that the term excludes provisions of industrial agreements, whether or not compulsory, unless they put into effect compulsory insurance as required by law or set up a scheme administered by the same institution as that which administers the scheme set up by law. In either of those cases, a Member State may have specified those schemes to which the Regulation applied. The third subparagraph went on to state that '[t]he provisions of the preceding subparagraph shall not have the effect of exempting from the application of this Regulation the schemes to which Regulation No 3 applied'. Regulation 3, which was replaced by Regulation 1408/71, was

\footnotetext{
86 Council Regulation (EEC) 1408/71 on the application of social security schemes to employed persons and their families moving within the Community [1971] OJ L149/2.

87 Council Regulation (EEC) 574/72 fixing the procedure for implementing Regulation (EEC) No 1408/71 on the application of social security schemes to employed persons and their families moving within the Community [1972] OJ L74/1.

88 JC Decision 76/2011 amending Annex VI (social security) and Protocol 37 to the EEA Agreement [2011] OJ L262/33.

89 Council Regulation (EC) 988/2009 amending Regulation (EC) No 883/2004 on the coordination of social security systems, and determining the content of its Annexes [2009] OJ L284/43.

90 Commission Regulation (EU) 1244/2010 amending Regulation (EC) No 883/2004 on the coordination of social security systems and Regulation (EC) $987 / 2009$ laying down the procedure for implementing Regulation (EC) 883/2004 [2010] OJ L338/35.

91 Council Directive 98/49/EC on safeguarding the supplementary pensions rights of employed and self-employed persons moving within the Community [1998] OJ L209/46.
} 
never applicable to the EEA-EFTA States. Similarly, Article 94(9), which related to family allowances due to persons subject to French legislation from 15 November 1989, did not apply; nor did Articles 95b and 96, which concerned redundant matters. There was also a list of country-specific amendments to the annexes of the Regulation so as to accommodate the EEA-EFTA States. The old implementing Regulation also applied, as amended and updated, and with only country-specific adaptations to the annexes of the Regulation. Finally, Directive 98/49 applied without adaptations.

One major measure not implemented in Annex VI is Regulation $859 / 2003$ extending the provisions of Regulation 1408/71 to third country nationals. ${ }^{92}$ This is still the case in the EU, where the old rules will continue to apply until it is amended. ${ }^{93}$ However, Regulation 859/2003 was never incorporated into the EEA Agreement. The result is that third country nationals will benefit from Regulation 1408/71 in EU Member States but from nothing at all in the EEA-EFTA States. It is easy to imagine the complexities which could arise as a result of complex, crossborder and multinational family arrangements.

For completeness' sake, it should also be noted that Annex VI, and Annex VI as it stood prior to amendment, contains a long list of decisions and other measures of which the Contracting Parties shall take due account or shall take note. ${ }^{94}$

It is possible to see in this part of the agreement another threat to the project's homogeneity as a result of the evolving acquis on citizenship. White notes that the ECJ has already adopted wide interpretations of the rights under the Regulations which enhance the free movement rights of workers. ${ }^{95}$ ' $\left.\mathrm{I}\right] \mathrm{t}$ is perfectly likely that the Court will in due course also

\footnotetext{
92 Council Regulation (EC) 859/2003 extending the provisions of Regulation (EEC) No $1408 / 71$ and Regulation (EEC) No 574/72 to nationals of third countries who are not already covered by those provisions solely on the ground of their nationality [2003] OJ L124/1.

93 White (n 28) 163.

94 Examples in the 'take due account' category are Decisions relating to the granting of prosthesis, major appliances and other substantial benefits in kind (Decision 115/1982 [1983] OJ C193/7), the implementation of certain articles of the social security co-ordinary Regulations (eg, Decision 105/1975 on the implementation of Article 50 of Council Regulation (EEC) No 1408/71 [1976] OJ C117/3), and the aggregation of insurance periods in a specific employment pursuant to Article 45(2) of Council Regulation (EEC) No 1408/71 (Decision 81/1973 [1973] OJ C75/9). In the 'take note' category, there is, for example, Recommendation 23/1975 concerning the issue of Form E 111 to workers posted abroad (adopted by the Administrative Commission during its 139th session on 23 January 1975) and Recommendation 20/1996 concerning improvement of the administration and settlement of reciprocal claims [1996] OJ L259/19.
}

95 White (n 28) 159. 
require consistency with the constitutional concept of citizenship of the Union'. ${ }^{96}$ The fact that citizenship is 'destined to be the fundamental status' and the fact that the Regulations apply to citizens support this proposition, as do the opinions of the Advocates-General in Teixeira and Ibrahim, two housing assistance cases. ${ }^{97}$ Finally, White cites Article 21(3) TFEU, which authorises the Council to adopt measures concerning social security or social protection so as to secure the right to move and reside freely. ${ }^{98}$

Should any such developments occur, it is not difficult to see what problems this might pose for the EEA Agreement, though this will depend on the EFTA Court. As Bruzelius predicted, we might see the disintegration of the EEA project. Alternatively, we may witness what will essentially be unjustifiable discrimination based on nationality and, at the very least, increasing complexity, especially where some family members are Union citizens and others are not. But as seen in Clauder, the Court did not even take the time to question whether the Directive should have been given a narrower interpretation owing to a lack of citizenship rights in the EEA Agreement, and the net result was that nationality of one of the EEA-EFTA States was equated, for the purposes of the Agreement, with Union citizenship. If free-movement citizenship rights do form part of the Agreement as has been suggested, and if the ECJ does subject the social security coordination rules to more citizenship compliance, then these interpretations could also seep into the EEA Agreement through EFTA Court jurisprudential development.

On 1 December 2011, Chris Grayling, Minister for the UK Department of Work and Pensions, announced that the UK government would launch actions for annulment in respect of the decisions to amend the EEA and Swiss agreements incorporating the new social security legislation. ${ }^{99}$ Case C-431/11 United Kingdom $v$ Council $^{100}$ concerning Council Decision $2011 / 407,{ }^{101}$ which sets out the Council's position, is pending before the ECJ. Based on fears that too much power to negotiate third country agree-

\footnotetext{
96 ibid.

97 Though it is conceded that the judgments were based on the rights of the children. ibid 161.

98 ibid.

99 I am grateful to Professor Robin White for alerting me to this. The initial statement on 1 December 2011 mentioned only the EEA (Written Ministerial Statements, 'Work and Pensions' HC (1 December 2011, column 77WS)) but it soon became clear that the proposed action related both to the EEA and Switzerland (European Scrutiny Committee, 'Coordination of Social Security within the European Economic Area-Application of the UK's JHA Opt-in' HC (2010-12) 1710(i) (oral evidence)).

100 Case C-431/11 United Kingdom $v$ Council (pending) [2011] OJ C311/26.

101 Council Decision 2011/407/EU on the position to be taken by the European Union within the EEA Joint Committee concerning an amendment to Annex VI (Social Security) and Protocol 37 to the EEA Agreement [2011] OJ L182/12.
} 
ments would be relinquished to the EU, ${ }^{102}$ the government's complaint is that Article 48 TFEU is not the correct legal basis for extending the Regulations to the EEA and Swiss agreements. Rather, Article 79(2)(b) TFEU, which concerns the rights of third country nationals residing legally in Member States, should have been the basis and, accordingly, the UK would not have opted-in to the extension. ${ }^{103}$ It will be interesting to see where the ECJ places the agreements and what consequences would follow from the fragmentation in the EEA that annulling this Decision would cause. ${ }^{104}$ If the UK gets its way, then the result could be the continued application of the old scheme in the UK as regards EEA-EFTA and Swiss nationals and the new system as regards EU nationals. Again, complexities could abound.

There is an argument to be made, however, that the extension of the social security legislation should be dealt with under Article 48 TFEU, that is, under the free movement of workers provisions, which is the legal basis for Regulation 1408/71 and Regulation 883/2004. The difficulty with this is that the Regulations do not necessarily apply solely to workers but also to self-employed and even economically inactive persons. Citizenship may compound this even further, for if European social security legislation is to be interpreted in light of citizenship, there could be a call for more sharply distinguishing between EU nationals and non-EU nationals. There is mounting pressure against homogeneity both from the constitutional concept of citizenship and from the competing interests of the various parties to the EEA Agreement. Unless the Contracting Parties renegotiate the legislative framework (or join the EU), the EFTA Court may be the only body able to confront and diffuse these problems in order to guarantee the goals of the EEA, its homogeneity, and its continued effective application. ${ }^{105}$ This will of course also depend on the behaviour of national courts, who are under no obligation to refer cases to the EFTA Court. But where citizenship-sensitive cases do come before the Court, it will be faced with these problems.

\footnotetext{
102 European Scrutiny Committee (n 99).

103 Under Protocol 21 to TEU, the UK can decide whether or not to opt-in to measures adopted under Title V of Part 3, TFEU, which includes measures adopted pursuant to Article 79 TFEU. Protocol (No 21) on the position of the United Kingdom and Ireland in respect of the Area of Freedom, Security and Justice, arts 1-2.

104 The UK has requested that the Decision remain valid until a new Decision, on the correct legal base, be adopted. Case C-431/11 United Kingdom v Council [2011] OJ C311/26, 26 (point (b) of the order sought by the UK).

105 It has been pointed out to me that the EFTA Court is not a constitutional court. This is entirely correct. However, the focus here is on the legal effect of its judgments, not necessarily their status. The Court has exhibited (an example being Arnulf Clauder) a tendency to rely on its own precedent and that of the ECJ. Similarly, although not strictly bound by the EFTA Courts, the referring courts do follow the EFTA Court's opinions (Lazowski 'EEA Countries' (n 3) 129). The effect of Arnulf Clauder has been to assimilate what is a constitutional concept into an international agreement which is devoid of it. How this is played out in the national courts and enforced by national authorities is another matter.
} 


\subsection{Transitional provisions}

Under Annex V and Annex VIII EEA, the transition periods for the 2004 and 2007 enlargements apply. In practice, these now only affect Bulgaria and Romania ${ }^{106}$ and they affect them in the same way vis-à-vis the EEA and the EU. The provisions are found in Annexes VI and VII to the 2005 Accession Treaty ${ }^{107}$ and essentially allow the EEA-EFTA States and EU Member States to apply national measures as regards Articles 1 to 6 of Regulation 1612/68 for two years after the date of accession (1 January 2007) and, if the Commission is notified, for up to five years after the date of accession. ${ }^{108}$ Further, where a Member State undergoes or is threatened by 'serious disturbances in its labour market', it may continue to apply national measure for up to seven years from the date of accession so long as the Commission is notified. ${ }^{109}$ If the Commission is not notified, then the Regulation shall apply. ${ }^{110}$ The last transitional arrangements will come to an end on 31 December 2013 at the latest. ${ }^{111}$

The reader should also note the possibility of a Contracting Party's invoking Article 112 EEA, which allows for unilateral measures in cases of serious economic, societal or environmental difficulties. This applies in respect of the Acts of Accession of 2003 and 2005, Annexes V and VIII EEA and a few other pieces of secondary legislation. ${ }^{112}$

As regards Liechtenstein in particular, sectoral adaptations, inserted by JC Decision 191/1999113 and subsequently replaced by the 2004 Enlargement Agreement, ${ }^{114}$ are found in Annex VIII and apply, as appro-

\footnotetext{
106 Restrictions on EU10 countries ended on 11 April 2011. Barnard (n 26) 264 and - 'Enlargement - transitional provisions' (information on transitional provisions) <http:// ec.europa.eu/social/main.jsp?catId=466\&langId=en> accessed 2 February 2012.

107 Act of Accession 2005 (Bulgaria and Romania) [2005] OJ L157/203.

108 ibid annex VI, chapter 1, paras 2-4 and annex VII, chapter 1, paras 2-4.

109 ibid annex VI, chapter 1, para 5 and annex VII, chapter 1, para 5.

110 ibid annex VI, chapter 1, paras 3 and 5 and annex VII, chapter 1, paras 3 and 5.

111 For the EU Member States which still have transitional provisions in place, see 'Bulgaria and Romania' (list of transitional provisions) <http://ec.europa.eu/social/main. jsp?catId=508\&langId=en $>$ accessed 13 March 2012.

112 Protocol 44 to the EEA Agreement on safeguard mechanisms pursuant to enlargements of the European Economic Area.

113 JC Decision 191/1999 amending Annexes VIII (Right of establishment) and V (Free movement of workers) to the EEA Agreement [2001] OJ L74/29.

114 Agreements in the form of an exchange of letters concerning the provisional application of the Agreement on the participation of the Czech Republic, the Republic of Estonia, the Republic of Cyprus, the Republic of Hungary, the Republic of Latvia, the Republic of Lithuania, the Republic of Malta, the Republic of Poland, the Republic of Slovenia and the Slovak Republic in the European Economic Area and the provisional application of four related agreements (Agreement on Enlargement 2004) [2004] OJ L130/3.
} 
priate, to Annex V. ${ }^{115}$ Having only 'a very small inhabitable area of rural character with an unusually high percentage of non-national residents and employees', ${ }^{116}$ Liechtenstein may require residents to hold work permits but is subject to specific minima as regards the number of them granted. ${ }^{117}$ Family members of nationals of the other Contracting States shall be granted the same rights as nationals residing in Liechtenstein and, if they take up economic activity, they shall be granted a permit. ${ }^{118}$ The arrangements also make provision for remaining persons, seasonal workers, frontier workers and procedural matters. ${ }^{119}$ Finally, Iceland and Norway may continue to apply certain restrictions on the establishment of persons in the fishing sectors, so long as they were in place on the date of signature of the Agreement. ${ }^{120}$

Concerning social security, Protocol 16 to the EEA Agreement on measures in the field of social security was concerned with seasonal workers in Liechtenstein. However, this was valid only as long as the transitional provisions in Protocol 15, which allowed Liechtenstein to apply its own national measures as regards entry and residence, remained valid. These expired on 1 January 1998.

\subsection{Future of the EEA}

The EEA Agreement has functioned fairly well for the past eighteen years. This is the conclusion of commentators ${ }^{121}$ and EFTA; ${ }^{122}$ and this conclusion should be cautiously endorsed. It has already been noted how citizenship is impacting the application of secondary rules in the Annexes, and the tensions this is causing have been highlighted - tensions which the EFTA Court has begun to resolve by silently assimilating nationality of the EEA-EFTA States with Union citizenship insofar as the free movement provisions of the EEA Agreement are concerned.

\footnotetext{
115 EEA Agreement, Annex V, Sectoral Adaptations, para 2.

116 Declaration by the EEA Council on free movement of persons attached to EEA Council Decision 1/95 on the entry into force of the Agreement on the European Economic Area for the Principality of Liechtenstein [1995] OJ L86/58, 80.

117 EEA Agreement, Annex VIII, Sectoral Adaptations, point II, para 1.

118 ibid, point III.

119 ibid points V-VIII.

120 EEA Agreement, Annex VIII, points 9 and 10. Iceland may impose restrictions on nonnationals and nationals without legal domicile in Iceland in the fisheries and fish processing sectors; Norway may restrict the establishment of non-nationals in fishing operations or that of companies owning or operating fishing vessels.

121 Eg Łazowski, 'EEA Countries' (n 3) 145-146 and Méndez-Pinedo (n 3) 308.

122 EFTA Annual Reports: 2004, 34; 2005, 18; 2006, 15; 2007, 14; 2008, 13; 2009, 14; 2010, 16. EFTA Annual Reports are available at <http://www.efta.int/publications/annual-report.aspx> accessed 13 March 2012.
} 
A 2008 report on the future of the EEA Agreement was published by the Joint Parliamentary Committee. Its authors recognised that expanding EU competences have resulted in soft and hard law measures which are not solely internal market relevant, such as the Citizens' Rights Directive. ${ }^{123}$ Particularly with this Directive, there were delays of about a year in its incorporation. The result was that the Annex nearly had to be suspended. ${ }^{124}$ Moreover, there were difficulties in negotiating the enlargement of the Agreement in 2007, which prevented the simultaneous enlargement of the EEA and EU. ${ }^{125}$ Croatia will soon accede to the EU and it is not clear if any difficulties will be caused thereby. And there is the question of Iceland's candidature for EU membership. If she accedes, it is questionable whether the EEA Agreement will continue to be viable with only Norway and Liechtenstein on the EEA-EFTA side. ${ }^{126}$ Although the Agreement has proved early scepticism wrong - much to the surprise even of the co-rapporteurs who authored the Future report ${ }^{127}$ - caution should be advanced in providing a positive prognosis in light of the free movement of persons provisions which are undoubtedly haunted by Union citizenship, a concept which does not form formally part of the EEA Agreement and which is clearly politically sensitive.

\section{EU-Swiss relations}

\subsection{The Swiss agreements ${ }^{128}$}

In contrast to the comprehensive EEA model, Switzerland's relations with the EU are marked by a host of sectoral and technical agreements

\footnotetext{
123 European Economic Area Joint Parliamentary Committee, Report on Future Perspectives for the European Economic Area (Brussels 2008) Ref 1087194, 5.

124 ibid 10.

125 ibid 5.

126 Méndez-Pinedo (n 3) 308, though legally it would not be impossible. There is also the doubtful possibility of a United Nordic Federation, encompassing both Iceland and Norway. G Wetterberg, 'The United Nordic Federation' (EU Observer 3 November 2010) <http:// euobserver.com/7/31188> accessed 29 February 2012. Cf A Rettman, 'Nordic Countries Huddle Together As World Gets Bigger' (EU Observer 6 December 2010) <http://euobserver. com/886/31329> accessed 29 February 2012.

127 European Economic Area Joint Parliamentary Committee (n 123) 10: '[T]hat the EEA still exists more or less in its original form and works as intended should perhaps be regarded as a surprise'.

128 Again, this is the barest overview. For more detailed discussion of the nature of the Agreements and EU-Swiss relations generally, see A Łazowski, 'Switzerland' in Blockmans and Łazowski (n 1); S Breitenmoser, 'Sectoral Agreements Between the EC and Switzerland: Contents and Context (2003) 40 CML Rev 1137; F Maiani, 'Legal Europeanization as Legal Transformation: Some Insights from Swiss "Outer Europe”" (2008) EUI Working Paper MWP No 2008/32; R Schwok, 'Switzerland's Approximation of its Legislation to the EU Acquis: Specificities, Lessons and Paradoxes' (2007) 9 European Journal of Law Reform 449; Tobler (n 3); M Vahl and N Grolimund, Integration without Membership - Switzerland's Bilateral Agreements with the European Union (Centre of European Policy Studies 2006).
} 
dating back to the late 1950s. ${ }^{129}$ The most important of these for this paper is one of a group of agreements referred to as Bilateral I. After the rejection of the EEA Agreement, the Commission published a communication setting out its stance on future relations with Switzerland. In it, the Commission identified, in particular, free movement of persons as a priority. ${ }^{130}$ Switzerland, keen to avoid adverse economic and political consequences, ${ }^{131}$ negotiated with the EU, inter alia, the Free Movement of Persons Agreement (FMPA). ${ }^{132}$ This came into force in June 2002, along with six other agreements. ${ }^{133}$ Sections 3.2-3.6 examines closely the rights granted under the FMPA. Before this, a few words on the institutional structure are in order to underscore the extent to which the Swiss legal framework differs from the EEA and to assess the Swiss model.

Much like the EEA Agreement, FMPA's main body refers to annexes which lay down detailed rules: Annex I on free movement of persons, Annex II on social security, and Annex III on mutual recognition of qualifications. However, the main agreement does not as such correspond to the EU Treaties. It lays down its own terms and refers to the Annexes. Annex I also lays down its own rules and refers to some EU legislation. Annexes II and III, on the other hand, refer exclusively to EU measures.

The judicial supervision of the agreement also differs as there is nothing akin to the EFTA Court. Article 16 of the Agreement obliges the Contracting Parties to take all measures required 'that rights and obligations equivalent to those contained in the legal acts of the European Community to which reference is made are applied in relations between them'. ${ }^{134}$ As for the case law of the ECJ, that which pre-dates 21 June 1999 shall be taken into account; post-signature case law shall be brought to Switzerland's attention and the Joint Committee may be called upon to determine the implications of such law. ${ }^{135}$ This being the

\footnotetext{
129 Vahl and Grolimund (n 120) 22-23.

130 Commission (n 4) 1.

131 Breitenmoser (n 128) 1137-1138 and Maiani (n 128) 3.

132 Agreement between the European Community and its Member States, of the one part, and the Swiss Confederation, of the other, on the free movement of persons [2002] OJ L1 14/6 (FMPA).

133 Agreements on research, technical barriers to trade, air transport, land transport, agriculture and public procurement.

134 FMPA, art 16(1).

135 ibid art 16(2). The reader will note the similarity between the pre- and post-signature case-law interpretation requirement in this and the EEA agreements. There are two essential differences, however. Firstly, pre-signature case law in the Swiss Agreement is only to be taken into account. There is a much stronger obligation under the EEA Agreement to interpret in conformity with the relevant rulings of the ECJ. Secondly, post-signature case law in the Swiss Agreement is simply to be brought to the attention of Switzerland. This is compared with the EFTA Court's obligation to take due account of it.
} 
situation, the agreement is highly dependent upon the Swiss judiciary for a Euro-compatible interpretation in accordance with Switzerland's obligations under the Agreement. ${ }^{136}$ Considering the autonomous application of Swiss law by Swiss judges ${ }^{137}$ and the fact that even the ECJ does not consider Switzerland to be part of the internal market, ${ }^{138}$ harmony in the interpretation and application of the Agreement could, depending on Swiss judicial behaviour, be rendered much more difficult, or impossible, in the long term. ${ }^{139}$

FMPA is a mixed agreement between Switzerland, on the one hand, and the EU and its Member States, on the other. As with the EEA Agreement, amendments to FMPA therefore require renegotiation, including on enlargement of the EU, with all the EU Member States in addition to the EU. ${ }^{140}$ Amendments to the Annexes are carried out in accordance with Article 18 FMPA which stipulates that the Contracting Parties may submit proposals to the EU-Swiss Joint Committee. If the proposal relates to Annexes II or III, the Committee may adopt a decision which may enter into force immediately. If, however, the proposal relates to Annex I, the Contracting Parties will need to complete their internal procedures and, therefore, such an amendment will require renegotiation. There is no obligation to update the annex. ${ }^{141}$ As will be seen throughout the rest of this article, the non-implementation of Directive 2004/38 has caused a severe divergence between the free movement and residence rights of Swiss and EU/EEA nationals.

\footnotetext{
136 Eg FMPA, art 16(1).

137 '[W]ithout taking into account EU legal materials'. Maiani (n 128) 16; Breitenmoser (n 128) 1147-1148.

138 Case C-351/08 Christian Grimme v Deutsche Angestellten-Krankenkasse [2009] ECR I-10777 [27]; Case C-541/08 Fokus Invest AG v Finanzierungsberatung-Immobilientreuhand und Anlageberatung GmbH [2010] ECR I-1025 [26]-[32]; Case C-70/09 Alexander Hengartner and Rudolf Gasser $v$ Landesregierung Vorarlberg [2010] ECR I-7229 [41]; Tobler (n 3) 9.

139 Unfortunately, there is not sufficient space to conduct a survey of the case law of the ECJ or Swiss courts to determine the extent to which the former's jurisprudence affects the application of the FMPA. What is presented below is a legislative comparison of the Swiss system to that operating in the EU and EEA. For the ECJ case law on free movement, the reader is directed to the standard texts.

140 Vahl and Grolimund (n 128) 72.

141 Tobler (n 3) 18 notes that the obligation under the EEA Agreement on the EEA JC is to 'take a decision concerning an amendment of an Annex to this Agreement', and she writes that this is an obligation to amend the Agreement. This is compared with the mere possibility in the Swiss FMPA of amendment. However, an obligation to take a decision to amend the Agreement is not an obligation to amend the Agreement. The decision may be to deliberately not incorporate a piece of legislation, as Switzerland has done with Directive 2004/38. Politically speaking, this might be untenable but is not so legally.
} 


\subsection{Free movement and residence rights ${ }^{142}$}

The main objectives of FMPA as outlined in Article 1 are, 'for the benefit of nationals of [EU Member States] and Switzerland, ${ }^{143}$ to accord a right of entry, residence, access to work, establishment and to stay; to facilitate the provision of services; to accord a right of entry and residence for non-economically active persons; and to accord the same living, employment and working conditions as accorded to home nationals. A prohibition on discrimination on the grounds of nationality, to be read in accordance with the Annexes, is found in Article 2.

Directive 2004/38 has not been incorporated into the Agreement. The applicable law is a mix of substantive provisions in the Annex itself and direct references to some (old) EC/EU measures. The system in place under FMPA is characterised by general rights of movement and residence which are substantiated by residence or special permits valid for minimum time periods. Under Directive 2004/38, the free movement and residence rights are explicit and the documentation formalities are just that: formalities. There is no need to 'substantiate' the right with a permit, and Directive 2004/38 does not even provide for issuing residence permits - only residence cards. Because of this, a straightforward conceptual comparative analysis is not easy. The following material will therefore be presented in such a way that makes a comparison between the rights under the two systems clearer by focusing on the substantive rights first and the formalities second.

Substantive rights of movement and residence are found in the main body of the Agreement. Article 3 provides for a right of entry, Article 4 a right of residence and access to an economic activity and Article 6 a right of residence for persons not pursuing an economic activity. Article 7 provides 'other rights': equal treatment in matters of living, employment and working conditions; occupational and geographical mobility; the right to remain once economic activity has ceased; residence of family members; acquisition of immovable property so far as this is linked to the rights conferred by the agreement; and the right, after an economic activity has ceased, to return to the territory of a Contracting Party to carry out an economic activity there during the transitional period. ${ }^{144}$ All of these articles make reference to the provisions found in Annex I.

142 The web of law which existed before Directive 2004/38, and which is the basis for the Swiss FMPA, was complex to say the least. For readers unfamiliar with it, the following text may be of some use: J Handoll, Free Movement of Persons in the EU (John Wiley \& Sons 1995).

143 FMPA, art 1.

144 ibid art 7(a)-(g). See section 3.5 below for the transitional provisions. 


\subsubsection{Entry and exit}

The entry and exit rules are very similar in both the Swiss and EU regimes, a reality reflected by the fact that Switzerland is party to Schengen. In Article 5(1) of Directive 2004/38 and Article 1(2) of FMPA Annex I, a right of entry is granted to nationals of other Member States / Contracting Parties who carry a valid passport or identity card. No visa requirements may be imposed upon Union citizens / nationals of the other Contracting Parties. Visas may only be required of third-country national family members and 'every facility to obtain the necessary visas' must be granted. ${ }^{145}$ In the EU, this is regulated by Regulation 539/2001 ${ }^{146}$ and an 'accelerated procedure' for granting visas free of charge is required. ${ }^{147}$ These latter requirements do not appear in the Swiss framework.

A very similar right of exit is also supplied in both regimes: nationals of the Member States and Switzerland have the right to exit the host territory upon the production of a passport or identity card. The States must also issue and renew for their own nationals an identity card or passport, which must be valid for all the territories through which the holder must pass. Where identity cards are not issued, a passport must be valid for at least five years. ${ }^{148}$ The only difference is that in the EU no exit visa or similar requirements may be imposed on the Union citizen or his family members, ${ }^{149}$ whereas in the FMPA this only applies to nationals of other Contracting Parties. ${ }^{150}$

\subsubsection{Right of residence}

By Article 2 of the Annex, nationals of the Contracting Parties derive a right of residence in the host state provided they fulfil the conditions laid down throughout the rest of the Annex.

\subsubsection{Employed persons.}

An employed person who is employed for more than one year is to be issued by the host state with a residence permit valid for five years and renewable automatically for five years. The first time it is renewed,

\footnotetext{
145 Directive 2004/38, art 5(1)-(2). FMPA Annex I art 1(1) second paragraph reads: '...for obtaining any necessary visas'.

146 Council Regulation (EC) 539/2001 listing the third countries whose nationals must be in possession of visas when crossing the external borders and those whose nationals are exempt from that requirement [2001] OJ L81/1.

147 Directive 2004/38, art 5(2) second paragraph.

148 ibid art 4 and FMPA Annex I, art 1(2).

149 Directive 2004/38, art 4(2).

150 FMPA Annex I, art 1(2) second paragraph, final sentence.
} 
the period of validity may be limited, but not to less than one year, where the person has been involuntarily unemployed for twelve consecutive months. ${ }^{151}$ For periods of employment of more than three months but less than one year, a permit valid for the duration of employment is to be issued, and an employee employed for up to three months does not require a residence permit. ${ }^{152} \mathrm{~A}$ distinction is drawn between workers and frontier workers: the latter do not require a residence permit in the host state but they may be required to have a special permit valid for five years and renewable on the same basis as those of non-frontier workers. ${ }^{153}$ Residence and special permits are valid throughout the territory of the host state, where the worker must be granted occupational and geographical mobility. ${ }^{154}$ It is also stipulated that a residence permit may not be withdrawn where the worker is temporarily unemployed because of accident or illness or involuntary unemployment; ${ }^{155}$ nor shall breaks in residence of less than six consecutive months (or longer for military service) lead to the invalidity of a residence permit. ${ }^{156}$ Workers may be prohibited from access to employment involving the exercise of public power. ${ }^{157}$

\subsubsection{Jobseekers.}

Jobseekers are dealt with in the second paragraph of Article 2(1) of the Annex. They are entitled to visit another Contracting Party or to remain there after employment of a period up to one year in order to seek employment. They may reside there for up to six months ('a reasonable amount of time' ${ }^{\prime 158}$ ). Jobseekers have the right to the same assistance afforded by employment agencies to home nationals, but they may be excluded from social security schemes for the duration of their residence. ${ }^{159}$ Jobseekers' rights are extended under Directive 2004/38 so that no expulsion measure may be brought against a jobseeker or his family members so long as he can provide evidence that he is seeking work and has a genuine chance of being engaged, ${ }^{160}$ though he might not be entitled to social assistance during this time. ${ }^{161}$

\footnotetext{
151 ibid art 6(1).

152 ibid art 6(2).

153 ibid art 7.

154 ibid art 6(4), 7(3) and 8.

155 ibid art 6(6).

156 ibid art 6(5).

157 ibid art 10.

158 ibid art 2(1), second paragraph, first sentence.

159 ibid art 2(1), second paragraph.

160 Directive 2004/38, art 14(4)(b).

161 ibid art 24(2).
} 


\subsubsection{Self-employed persons.}

Non-salaried nationals wishing to establish themselves must also be issued with a residence permit valid throughout the host territory ${ }^{162}$ for at least five years, provided evidence is produced that shows they are self-employed or wish to become so. This is automatically extendible for five years on production of evidence that the individual is actually selfemployed. ${ }^{163}$ As with workers, a permit cannot be withdrawn merely because self-employed activity has stopped owing to illness or accident. ${ }^{164}$ Self-employed frontier workers also do not need a residence permit but may be required to have a special permit on the same terms as non-frontier self-employed persons. ${ }^{165}$ And again, as with workers, self-employed persons have the right to occupational and geographical mobility ${ }^{166}$ and may be denied the right to pursue activity involving the exercise of public authority. ${ }^{167}$

\subsubsection{Non-economically active persons and students.}

Economically inactive nationals - those who neither work nor undertake self-employed activity - may receive a residence permit valid for at least five years provided that they have sufficient financial means not to have to apply for social assistance benefits and that they have all-risks sickness insurance cover. The residence permit may be revalidated after two years. ${ }^{168}$ Financial means are considered sufficient if they exceed the amount below which host nationals become entitled to social security benefits or if they are greater than the level of minimum social security pensions paid to host nationals. ${ }^{169}$ An exception is that persons who have been working for less than a year may have unemployment benefits to which they are entitled under national law considered part of their financial means. ${ }^{170}$ These residence permits are extendible for at least five years provided the eligibility criteria are met. ${ }^{171}$

Students are entitled to a residence permit of up to one year, renewable each year, provided they can declare that: they are registered in an

\footnotetext{
162 FMPA Annex I, art 12(4).

163 ibid art 12(1)-(2).

164 ibid art 12(6).

165 ibid art 13.

166 ibid art 14.

167 ibid art 16.

168 ibid art 24(1).

169 ibid art 24(2).

170 ibid art 24(3).

171 ibid art 24(5).
} 
approved establishment and are pursuing a vocational training course; have all-risks sickness insurance; and have sufficient financial means so as to not make a claim for social security in the host state. ${ }^{172}$ By contrast, under Directive 2004/38, if students wish to stay for longer than three months, a student must be enrolled at a "public or private establishment, accredited or financed by the host Member State ... for the principle purpose of following a course of study, including vocational training' and he must have comprehensive sickness insurance and be able to declare that he has 'sufficient resources for [himself] and [his] family members not to become a burden on the social assistance system of the host'. ${ }^{173}$ This is much wider than the provision made under the Swiss FMPA.

As with the other categories, for students and other non-economically active individuals, breaks in residence of less than six months, or longer for military service, shall not invalidate the residence permit, ${ }^{174}$ which is valid throughout the host territory. ${ }^{175}$

\subsubsection{Comparison.}

The contrast between the scheme still operating in the Swiss framework and that of Directive 2004/38 can easily be seen. Although a similar picture is seen in the Swiss system, the Directive presents a clear hierarchy of rights of residence: right of residence of up to three months, unconditionally; ${ }^{176}$ right of residence of between three months and five years, conditional upon economic activity or self-sufficiency; ${ }^{177}$ and the novel right of permanent residence following completion of five years' continuous lawful residence, without any economic sufficiency criteria. ${ }^{178}$ Once permanent residence is obtained, a concept which is wholly absent from the Swiss agreement, then Union citizens and their family members are almost equated with nationals of the host state. It should also be noted that the Directive does not draw a distinction between frontier and non-frontier workers, whereas the Swiss agreement does.

The financial eligibility criteria are different also. It is no longer the case that an individual needs to show that he will not make any claim on the social assistance system of the host state, just that he will not

\footnotetext{
172 ibid art 24(4).

173 Directive 2004/38, art 7(1)(c).

174 FMPA Annex I, art 24(6).

175 ibid art 24(7).

176 Other than on production of a valid passport or identity card. Directive 2004/38, art

6.

177 ibid art 7.

178 ibid art 16.
} 
become a 'burden' on it. ${ }^{179}$ Additionally, expulsion shall not be the automatic consequence of recourse to the social assistance system of the host. ${ }^{180}$ In determining what resources are considered sufficient for the purposes of the Directive, there is the added requirement that a Member State must take into account the individual's personal situation. ${ }^{181}$

The periods of absence permitted in calculating the length of residence for the purposes of obtaining permanent residence have been expanded. Before, only breaks of less than six months or longer for military service would not interrupt the validity of a residence permit. Under Directive 2004/38, the following will not affect the acquisition of permanent residence: breaks of up to a total of six months in the year, or longer for military service, or of one absence of up to twelve consecutive months 'for important reasons such as pregnancy and childbirth, serious illness, study or vocational training, or a posting in another Member State or a third country'. ${ }^{182}$ Once obtained, permanent residence can only be lost through absence for a period of two or more consecutive years. ${ }^{183}$

\subsubsection{Right to remain}

Nationals of a Contracting Party and their family members have the right to stay in the host territory after their economic activity has finished. ${ }^{184}$ Reference is made to Regulation $1251 / 70^{185}$ and Directive $75 / 34^{186}$ which applies the provisions of Regulation 1251/70 mutatis mutandis to self-employed persons. These measures stipulate that workers or self-employed persons may remain permanently in the host state in three circumstances: (a) having worked for at least one year and having resided for at least three, the person has reached the age at which host nationals become entitled to old-age pension; ${ }^{187}$ (b) having resided for two or more years, the person is rendered incapable of work; or (c) frontier persons who work in another state and return to the host state, as a

\footnotetext{
179 ibid art 7(1)(b) and, for students, (c).

180 ibid art 14(3).

181 ibid art 8(4).

182 ibid art 16(3).

183 ibid art 16(4).

184 FMPA Annex I, art 4.

185 Commission Regulation (EEC) $1251 / 70$ on the right of workers to remain in the territory of a Member State after having been employed in that State [1970] OJ L142/24.

186 Council Directive 75/34/EEC concerning the right of nationals of a Member State to remain in the territory of another Member State after having pursued therein an activity in a self-employed capacity [1975] OJ L14/10.

187 Or 65 years if the host does not grant old-age pensions to certain self-employed persons.
} 
rule, once a day, for three years. ${ }^{188}$ Family members may remain with the worker or self-employed person once he obtains the right to permanently remain, even after his death. ${ }^{189}$ But if the worker or self-employed person died 'during his working life', 190 then his family members can remain provided that the person had resided continuously for at least two years, his death resulted from an occupational accident or disease, or the surviving spouse is a host national, or lost host nationality through marriage. ${ }^{191}$

The right of permanent residence under Article 16 of Directive 2004/38 can, in circumstances similar to those just outlined, also be obtained under Article 17. The only difference between the two schemes as regards the Union citizen is that where the host state does not grant old-age pension to certain self-employed workers, the minimum age necessary for obtaining permanent residence in circumstance (a) is 60, rather than $65 .{ }^{192}$ Family members are entitled to remain if the citizen dies while still working but before obtaining permanent residence on the same conditions, ${ }^{193}$ but the right to stay upon the 'death or departure' of the Union citizen is governed by Article 12, which grants the right to remain regardless of time, so long as the family member either satisfies the Article 7 financial eligibility criteria or has obtained permanent residence. ${ }^{194}$ There is also the added protection that the parent who has custody of the children who reside in the host may not be expelled, regardless of nationality, until the children have completed their studies. ${ }^{195}$

\subsubsection{Equal treatment}

The equal treatment provisions are spread throughout the Agreement and Annex. Article 2 of the Agreement, which provides for non-discrimination, has already been noted. Article 9 of the Annex lays down the main equal treatment provisions for workers and applies, mutatis mutandis, to self-employed persons by virtue of Article 15 of the Annex.

Article 9 of the Annex mirrors Articles 7-9 of Regulation 1612/68 and Regulation 492/2011. Therefore, workers receive the same equal treatment rights, which include equal treatment as to terms of (re-)employment and working conditions, tax concessions and welfare benefits,

\footnotetext{
188 Regulation 1251/70, art 2 and Directive 75/34, art 2.

189 Regulation 1251/70, art 3(1) and Directive 75/34, art 3(1).

190 This is changed to 'while still working' in Directive 2004/38, art 17(4).

191 Regulation 1251/70, art 3(2), Directive 75/34, art 3(2).

192 Directive 2004/38, art 17(1)(a).

193 ibid art 17(4).

194 ibid art 12(1)-(2).

195 ibid art 12(3).
} 
vocational education and re-training, ${ }^{196}$ non-discrimination in collective or individual arrangements concerning access to employment or its terms, non-discrimination as to membership of trade unions and nondiscrimination as to housing rights. ${ }^{197}$ Whilst workers have the same rights in the EU under the Regulation, the provisions under Directive 2004/38 are much broader. By Article 24 of the latter, all Union citizens residing on the basis of the Directive (whether employed, self-employed, a student, retired, as a pensioner, or as a family member) shall receive equal treatment to host nationals. This is extended to family members who are not Union citizens. ${ }^{198}$ The only derogations to this are that the host state is not obliged to confer social assistance in the first three months of residence or the longer period where an individual is seeking work; nor is the host state required to grant maintenance aid for studies other than to persons with permanent residence, workers, persons who are self-employed or their family members. ${ }^{199}$

\subsubsection{Family members}

Another major difference between the Swiss regime and that operating in the EU is the meaning of 'family member'. Under Directive 2004/38, 'family member' includes the spouse or, where the host state recognises such partners, the partner of the Union citizen; his direct descendants under the age of 21 or dependants and those of his spouse or partner; and the dependent relatives in the ascending line and those of his spouse or partner. ${ }^{200}$ There is also a further duty on the host state to 'facilitate entry and residence' of any other family members who, in the home country, are dependants or members of the Union citizen's household, or where serious health grounds strictly require the care of the family member; and the partner of a Union citizen who shares a durable relationship, duly attested. ${ }^{201}$ However, FMPA only recognises the spouse, descendants under the age of 21 and dependants; relatives in the ascending line of the individual or his spouse; and, in the case of a student, his spouse and their children. Registered partners and those recognised by Article 3 of Directive 2004/38 are excluded. There is also an additional requirement in the Swiss regime that an employed person

\footnotetext{
196 FMPA stipulates 'education in vocational training establishments and in vocational retraining and occupational rehabilitation centres' (Annex I, art 9(3)) whereas the EU Regulations stipulate 'training in vocational schools and retraining centres' (Regulation 1612/68, art 7(3) and Regulation 492/2011, art 7(3)).

197 FMPA Annex I, art 9 and Regulations 1612/68 and 492/2011, arts 7-9.

198 Directive 2004/38, art 24(1).

199 ibid art 24(2).

200 ibid art 2(2)(a)-(d).

201 ibid art 3(2)(a)-(b).
} 
must possess housing for his family which is regarded as of normal standard for national employed persons in the region where he is employed' provided that this does not lead to discrimination between host and other nationals. ${ }^{202}$ This was originally found in Article 10 of Regulation 1612/68. ${ }^{203}$ The fact this requirement remains in the Swiss system highlights the disparity between the rights granted under it and those under Directive 2004/38 and the impact on homogeneity this has.

The family members, with the exception of ascendants, are entitled to take up an economic activity whatever their nationality. ${ }^{204}$ This is narrower than Directive 2004/38, whereby all family members, whatever their nationality, who have the right of residence or permanent residence (which they can gain by moving and residing with their Union citizen family member ${ }^{205}$ ) are to be treated equally to host nationals within the scope of the Treaty. ${ }^{206}$

As is the case under Regulation $492 / 2011,{ }^{207}$ children must be admitted to educational programmes in the host state if they reside in its territory, and the host state must promote initiatives to allow those children to attend under the best possible conditions. ${ }^{208}$

\subsubsection{Public order exceptions}

Article 5 of the Annex allows restrictions on the grounds of public order, ${ }^{209}$ public security or public health and reference is made to Directives $64 / 221,{ }^{210} 72 / 194^{211}$ and $75 / 35^{212}$ - the latter two of which

\footnotetext{
202 FMPA Annex I, art 3(1).

203 Regulation 1612/68, art 10, was repealed by Directive 2004/38, art 38(1), which, in turn, was repealed by Regulation 492/2011, annex I.

204 FMPA Annex I, art 3(5).

205 Directive 2004/38, arts 7(1)(d), 7(2) and 16(2).

206 ibid art 24.

207 Regulation 492/2011, art 10. This also appeared in Regulation 1612/68, art 12.

208 FMPA Annex I, art 3(6).

209 Nothing seems to turn on the fact that the words 'public order' are used in FMPA in place of 'public policy', especially considering that EC Directives, which contain references to 'public policy', are referred to.

210 Council Directive 64/221/EEC on the coordination of special measures concerning the movement and residence of foreign nationals which are justified on grounds of public policy, public security or public health [1964] OJ 56/850.

211 Council Directive 72/194/EEC extending to workers exercising the right to remain in the territory of a Member State after having been employed in that State the scope of the Directive of 25 February 1964 on coordination of special measures concerning the movement and residence of foreign nationals which are justified on grounds of public policy, public security or public health [1972] OJ L121/32.

212 Council Directive 75/35/EEC extending the scope of Directive No 64/221/EEC on the coordination of special measures concerning the movement and residence of foreign
} 
extend Directive 64/221 to persons residing on the basis of Regulation $1251 / 70$ and Directive 75/34 respectively. The scheme operable in Directive 2004/38 also provides for such exceptions and on similar terms. However, the safeguards are far more stringent in the latter than in the EU-Swiss system. Articles 30 to 33 of Directive 2004/38 lay down strict procedural requirements for an expulsion order to be lawful. Under both regimes, an individual must be notified of an expulsion order against him, ${ }^{213}$ but Directive 2004/38 requires that this be in writing, specifying which court or administrative authority has jurisdiction to hear an appeal. ${ }^{214}$ Judicial or administrative redress is guaranteed by both, ${ }^{215}$ but the later Directive specifies the circumstances under which the removal may take place. ${ }^{216}$ Additionally, only Directive 2004/38 requires that an individual may apply to have an exclusion order lifted in a reasonable time and in any event after three years; ${ }^{217}$ and where an exclusion order is to be carried out two years after it was issued, the authorities must check that the individual is still a current threat. ${ }^{218}$

Further, the types of diseases or disabilities which justify refusal on public health grounds differ. Directive 64/221 lists six diseases or types of disease ${ }^{219}$ whereas Directive 2004/38 refers to diseases which have epidemic potential as defined by the World Health Organization and other infectious diseases or contagious parasites in respect of which controls apply to host nationals, ${ }^{220}$ which is a potentially broader exception.

\subsubsection{Formalities relating to residence permits and reporting presence}

Residence is substantiated by a residence permit in the host state under the Swiss Agreement, ${ }^{221}$ whereas under Directive 2004/38 resi-

nationals which are justified on grounds of public policy, public security or public health to include nationals of a Member State who exercise the right to remain in the territory of another Member State after having pursued therein an activity in a self-employed capacity [1975] OJ L14/14.

213 Directive 64/221, art 6 and Directive 2004/38, art 30(1).

214 Directive 2004/38, art 30.

215 Directive 64/221, arts 8-9 and Directive 2004/38, art 31(1).

216 Directive 2004/38, art 31(2)-(4). The right to submit a defence is guaranteed by both Directive 64/221, art 9(1), second paragraph and Directive 2004/38, art 31(3).

217 Directive 2004/38, art 32.

218 ibid art 33.

219 Directive 64/221, art 4 and the Annex to the same Directive. These are: (1) diseases subject to quarantine under International Health Regulation No 2 of the World Health Organization of 25 May 1951; (2) tuberculosis; (3) syphilis; (4) other infectious diseases or contagious parasites if host nationals are subject to controls in respect of them; (5) drug addiction; (6) profound mental disturbance and some other mental illnesses.

220 Directive 2004/38, art 29(1).

221 FMPA Annex I, art 2(1). 
dence cards are merely indicative of a free-standing right granted under EU law, primarily by the Treaty. The Directive states that the rights can in fact be attested 'by any other means of proof'. ${ }^{222}$ The rights substantiated by residence permits, and hence their length and validity, have been dealt with above. This section will deal with the formalities.

Residence permits must be granted free of charge or on payment of a sum equivalent to that payable for the issue of identity cards to host nationals. ${ }^{223}$ Formalities and procedures for issuing residence permits must be simplified. ${ }^{24}$ The Contracting Parties may require all nationals of other Contracting States to report their presence, regardless of length of stay. ${ }^{225}$ Persons residing on the basis of Regulation 1251/70 (remaining after employment has ceased) shall be granted residence permits on the same terms. ${ }^{226}$ Family members must be granted residence permits which are the same as those issued to "the person on whom he is dependent ${ }^{227}$ and the host state may require (only): the document by which the family member entered the territory, a document issued by the competent authority of the home state proving the relationship, and, for dependants, a document issued by the home state showing that they live in the same household. ${ }^{228}$ Expiry of the passport or identity card used to enter the host shall not justify expulsion from the territory. ${ }^{229}$

The differences under Directive 2004/38 mainly reflect the redistribution of substantive rights. For periods of less than three months, nationals are not required to register, ${ }^{230}$ and the Directive supplies strict rules for issuing registration certificates. ${ }^{231}$ The Directive does not stipulate that any card or permit be issued to Union citizens (or, by analogy, EEA nationals). For Union citizen family members, the expanded categories are reflected in the documentation which a host state may require. ${ }^{232}$ One major development is that non-Union citizen family members may be issued with residence cards (not permits) and the deadline for applying for one may not be less than three months from arrival. Sanctions

\footnotetext{
222 Directive 2004/38, art 25.

223 FMPA Annex I, art 2(3).

224 ibid art 2(3).

225 ibid art 2(4).

226 That is, free of charge or at a price equivalent to the issue of identity cards to host nationals. Regulation 1251/70, art 6(1).

227 FMPA, Annex I, art 3(4).

228 ibid art 3(3)(a)-(c).

229 Directive 64/221, art 3(3).

230 Directive 2004/38, art 8(1).

231 ibid art 8(2).

232 ibid art 8(5).
} 
for failure to comply must be proportionate and non-discriminatory ${ }^{233}$ and the Directive stipulates what evidence may be required by the host state. ${ }^{234}$

\subsection{Mutual recognition of qualifications}

Once EU-Swiss Joint Committee Decision 2/2011 ${ }^{235}$ comes fully into force, ${ }^{236}$ Directive 2005/36 will be incorporated almost entirely into Annex III of the Agreement. Numerous adaptations relating to procedures for amending and updating the Directive are made (excluding Switzerland from the processes), along with numerous Swiss-specific additions to the Directive's annexes. ${ }^{237}$ One significant adaptation made is in relation to Article 61 of the Directive, which lays down a procedure whereby the Commission may allow derogations from the Directive in times of major difficulty - this does not apply in the Swiss adaptation of the Directive, with the result that such derogations will not be possible between Switzerland and the EU States without renegotiation. In addition to Directive 2005/36, six other instruments are referred to. ${ }^{238}$ As Annex III currently stands, 72 different measures are applicable. ${ }^{239}$

\subsection{Social security coordination}

Annex II on social security is set out as a three-part Annex. Section A lists measures which must be applied by the Contracting Parties, section B contains measures of which the Contracting Parties shall take due account, and section $\mathrm{C}$ contains measures of which they shall take note. They are all adapted so that references to 'Member State(s)' include

\footnotetext{
233 ibid art 9.

234 ibid art 10.

235 EU-Swiss Joint Committee Decision 2/2011 on the free movement of persons of 30 September 2011 replacing Annex III (Mutual recognition of professional qualifications) thereto [2011] OJ L277/20 (EU-Swiss Decision 2/2011).

236 This will be the day following the date of completion by Switzerland of its internal procedures for implementation. EU-Swiss Decision 2/2011, art 4. It has applied on a provisional basis, with the exception of Title II on the provision of services, since 23 December 2011. EU-Swiss Decision 2/2011, art 4.

237 Annex to EU-Swiss Decision 2/2011.

238 Namely, Directives 77/249, 98/5, 74/556, 74/557 and 86/653 and Recommendation 98/601, all of which are also incorporated under the EEA Agreement.

239 Including Council Directive 89/48/EEC on a general system for the recognition of higher-education diplomas awarded on completion of professional education and training of at least three years' duration [1989] OJ L19/16, Council Directive 92/51/EEC on a second general system for the recognition of professional education and training to supplement Directive 89/48/EEC [1992] OJ L209/25, the legal services Directives (77/249 and 98/5) and many sector specific Directives, Communications and Recommendations.
} 
references to Switzerland. ${ }^{240}$ A protocol forming an integral part of the Annex makes special provision for unemployment insurance for workers holding a Swiss residence permit valid for less than a year. ${ }^{241}$

EU-Swiss Joint Decision 1/2012 $2^{242}$ replaced, as of 1 April 2012, the Regulation 1408/71 scheme with the new Regulation 883/2004 system. Section A of the Annex now contains Regulation 883/2004, as amended by Regulation 988/2009, and Regulation 987/2009. These are unadapted, except for Swiss-specific adaptations to the Annexes of the Regulations. In addition, as in the EEA Agreement, Directive 98/49 applies and Regulation 859/2003 does not. The Annex also makes reference to Regulations 1408/71 and 574/72 'as applicable between Switzerland and the Member States before the entry into force of this Decision, and when referred to in Regulations (EC) No 883/2004 or No 987/2009 or when cases are concerned which occurred in the past'. The social security coordination legislation in respect of Switzerland is, therefore, more or less the same as that applicable in the EEA Agreement, with all the attendant difficulties for the homogeneity of the internal market that were explored above in the context of the EEA Agreement. ${ }^{243}$

It is recalled that the action for annulment brought by the UK also affects the Swiss free movement agreement. Case C-656/11 ${ }^{244}$ concerns Council Decision 2011/863 on the position to be taken by the EU in the Swiss Joint Committee as regards the replacement of Annex II. ${ }^{245}$ The arguments are the same (wrong legal basis). The possible tensions which might be caused by an interpretation of the social security legislation in light of citizenship, should this happen, could be even more intense as regards the Swiss free movement model which does not have a superior court such as the EFTA Court, which is not as comprehensive as the EEA Agreement, and which is far less integrationist.

\footnotetext{
240 FMPA Annex II, art 1(2).

241 ibid art 3.

242 EU-Swiss Decision 1/2012 of 31 March 2012 replacing Annex II to [the FMPA] on the coordination of social security schemes [2012] OJ L103/51.

243 See notes 95-105.

244 Case C-656/11 United Kingdom v Council (pending) [2012] OJ C49/20. An application for interim relief was rejected by order of the President of the Court in Case C-656/11 R United Kingdom $v$ Council.

245 Council Decision 2011/863 on the position to be taken by the European Union in the Joint Committee established under the Agreement between the European Community and its Member States, of the one part, and the Swiss Confederation, of the other, on the free movement of persons as regards the replacement of Annex II to that Agreement on the coordination of social security schemes [2011] OJ L341/1.
} 


\subsection{Transitional provisions}

Transitional provisions are dealt with thoroughly elsewhere. ${ }^{246}$ The rules are provided in FMPA, Article 10, with detail in Articles 26 - 34 of Annex I and with further provision made in the two Protocols enlarging the Agreement. ${ }^{247}$ Most of the transitional arrangements have now expired save for the Article 10(4) procedure and those found in the Second Enlargement Protocol extending the Agreement to Bulgaria and Romania. The former allows Switzerland, in circumstances where the number of permits granted is abnormally high in a given year, and until 31 May 2014 (31 May 2019 in respect of Bulgaria and Romania), to unilaterally limit the number of permits for the succeeding year. The Second Enlargement Protocol allows Switzerland to maintain in force unilateral restrictions similar to those provided for in the original Agreement and First Enlargement Protocol. Switzerland may keep these in force until 31 May 2014.

\subsection{Future of EU-Swiss relations}

Switzerland has been called a quasi-Member State ${ }^{248}$ owing to the vast amount of law she has voluntarily approximated ${ }^{249}$ and because of her geographical, political and economic significance. ${ }^{250}$ However, such an assessment is not as easy to support in light of the above discussion. The current bilateral system has in the past received much support: Vahl and Grolimund wrote in 2006 that '[t]he bilateral agreements are functioning well'251 and that 'the two parties seem content with the bilateral sectoral approach'. ${ }^{252}$ It has been hailed as a model for Britain ${ }^{253}$ and it is the approach favoured, as late as August 2011, by the Swiss

\footnotetext{
246 Łazowski, 'Switzerland' (n 128) 177-181.

247 First EU-Swiss Enlargement Protocol [2006] OJ L89/30 and Second EU-Swiss Enlargement Protocol [2009] OJ L124/53.

248 Maiani (n 128) 1; R Schwok, Towards a Framework Agreement in the Context of New Bilateral Agreements between Switzerland and the European Union' in Maiani, Petrov and Mouliarova (n 1).

249 Estimates put the figure as high as 85\% of all Swiss law by 2000: Vahl and Grolimund (n 128) 50. Schwok writes that virtually all federal laws are pre-screened for Euro-compatibility. Schwok, 'Towards a Framework Agreement' (n 248) 125.

250 Swiss FDFA/FDEA, 'Switzerland's policy on the European Union' (2011) $1<\mathrm{http}$ // www.europa.admin.ch/themen/00499/index.html?lang=en\&download=NHzLpZeg7t,lnp6 IONTU04212Z6ln 1ad1IZn4Z2qZpnO2Yuq2Z6gpJCDdIR,fGym162epYbg2c_JjKbNoKSn6A-> accessed 8 March 2011; Łazowski, 'Switzerland' (n 128) 148; Breitenmoser (n 128) 1139.

251 Vahl and Grolimund (n 128) 105.

252 ibid 94.

253 G Ruffle, 'Switzerland and the European Union: A Model for Britain' (Global Vision commentary) (2008) <http://www.global-vision.net/files/downloads/download544.pdf> accessed 8 March 2012.
} 
Federal Council, who wish to continue with and to develop the bilateral framework. ${ }^{254}$ Indeed, for the Swiss Federal Council, any form of automatism would abrogate Swiss sovereignty and would therefore be unacceptable. ${ }^{255}$ This is at odds with the current position of the Council which, in December 2010, said:

[T]he Council has come to the conclusion that while the present system of bilateral agreements has worked well in the past, the key challenge for the coming years will be to go beyond that system, which has become complex and unwieldy to manage and has clearly reached its limits. ${ }^{256}$

To ensure the homogenous interpretation of the agreements, the Council desires independent dispute settlement, judicial and surveillance mechanisms. ${ }^{257}$ Because of a lack of such institutions, the Council notes, the agreements have failed to secure homogeneity. ${ }^{258}$ Whether this remains true in the free movement of persons context when the domestic situation of any given Member States is considered is another question for another day. ${ }^{259}$ With Croatia's impending membership, the future of the Agreement is in particular doubt. If a referendum is adverse to its extension, this could spell the end of all the Bilateral I agreements and Switzerland's participation in Schengen. ${ }^{260}$ If Switzerland wishes to

254 Swiss FDFA/FDEA (n 250) 10-11.
255 ibid 10.
256 Council of the European Union, 'Council conclusions on EU relations with EFTA countries' $3060^{\text {th }}$ General Affairs Council meeting, Brussels, 14 December 2010 [48].

257 ibid.

258 ibid [42]. It is not difficult to see why this is so when one considers the facts that free movement provisions are increasingly being interpreted with a view to citizenship, which certainly does not form any part of the Swiss agreements, and that it takes so long to incorporate new Union measures - as well as Swiss opposition to homogeneity. The Swiss decision of 18 April 2012 to re-establish quantitative restrictions on EU citizens should also be borne in mind. This decision received very severe criticism from the EU. Catherine Ashton, High Representative for Foreign Affairs, issued a statement in which she considered the move to be in breach of the Agreement and economically unjustified. (C Ashton, 'Statement on the Decision of the Swiss Government to Re-establish Quantitative Limitations for Certain Categories of Residence Permits as Regards EU Citizens Who Are Nationals of Eight of the EU Member States' (2012) A 182/12). The President of the European Parliament, Martin Schulz, made a similar statement on the same day ('Schulz on Decision of Swiss Government Decision to Reintroduce Restriction on 8 EU Member States' <http://www.europarl. europa.eu/the-president/en/press/press_release_speeches/press_release/2012/2012april/press_release-2012-april-10.html> accessed 29 July 2012.

259 As an example, in the UK, Swiss nationals are treated as EEA nationals. In fact, under the Immigration (European Economic Area) Regulations 2006 (SI 2006/1003), which is the measure which transposes Directive 2004/38 into English law, the term 'EEA State' includes Switzerland: r 2(1).

260 The seven Bilateral I agreements are linked by a guillotine clause: if one agreement should fail, they all fail. The EU-Swiss Schengen agreement does not have this but the latter 
retain its stake in the internal market, she may have to countenance membership of EEA or the EU - both technical possibilities but, seeing as there remains popular opposition to Europe, ${ }^{261}$ this possibility can be safely rejected. It will be exciting to see what happens next.

\section{Conclusion}

Two very different forms of internal market integration have been studied in this paper. The free movement and residence rights, and the mutual recognition of qualifications and social security co-ordination in the EEA system and in the context of EU-Swiss relations have been explored in detail and it is clear that homogeneity is better secured in the former than in the latter. Through integrationist interpretations by the EFTA Court, nationality of one of the EEA-EFTA States has almost been equated with Union citizenship, at least insofar as movement and residence goes. Owing to Directive 2004/38's incorporation into the EEA Agreement, no other conclusion would be viable. This may increasingly be the case if free movement law - and social security co-ordination - receives further citizenship-oriented interpretations from the ECJ. Though this, and the EFTA Court's response, may be good news for individuals who move among the Contracting Parties, there is serious legal inconsistency and murkiness between the concept of EU citizenship and its apparent exclusion from the EEA Agreement.

The situation in Switzerland is less happy from a homogeneity perspective. An older form of the law is in force. The only basis on which to decide whether a person can secure the old rights or the more effective ones under Directive 2004/38 is the arbitrary distinction of nationality: this is hardly conducive to ensuring European integration and social solidarity, though it may secure Swiss independence. At the very least, the clarity of the Agreement is maintained at the expense of homogeneity. Legally speaking, the FMPA is an interesting possible alternative to the EEA Agreement; but one which, by its very nature, grants nationals of different countries different rights in the same internal market.

cannot survive without FMPA. Łazowski, 'Switzerland' (n 128) 166 and Vahl and Grolimund (n 128) 54-55.

261 Vahl and Grolimund (n 128) 11 and 94. For a nuanced discussion of Swiss Euro-scepticism, see C Church, 'The Contexts of Swiss Opposition to Europe' (2003) Sussex European Institute Working Paper No 64, 'Opposing Europe Research Network' Working Paper No 11. 